\title{
Antropologia Politikoa: politikaren zientzia mota baten ondare teorikoa
}

\author{
Luis Miguel Uharte Pozas \\ Gizarte Antropologia Saileko irakaslea-ikertzailea (UPV/EHU)
}

\begin{abstract}
Antropologia Politikoa XX. mendeko 40ko hamarkadan sortu zen Gizarte Antropologiaren azpidiziplina gisa. 80 urte pasa ostean oihartzun nabarmena lortu du eta oso emankortzat jo dezakegu arlo teorikoan, baita ikerketa etnografikoen eremuan ere. Lan honek helburu nagusi bi ditu. Alde batetik, azpidiziplina honen deskribapen sakona egitea, haren ezaugarri nagusiak, gai esanguratsuenak eta ekarpen garrantzitsuenak azpimarratuz. Beste alde batetik, ikuspegi kronologiko batetik abiatuta, sortu zenez geroztik gaur egunera arte, haren korronte teoriko ezagunenak mahai gainean jartzea: aitzindariak, sortzaileak (estrukturalfuntzionalismoa), lehenengo kritikoak (ikuspegi prozesuala) eta korronte garaikideak. Bukatzeko, hainbat ondorio azpimarratzen dira etorkizunari begira.
\end{abstract}

GAKO-HITZAK: Antropologia Politikoa · Ondare teorikoa · Gai esanguratsuenak - Korronte-aniztasuna.

\section{Political anthropology: the theoretical legacy of a science of the political}

Political Anthropology emerged as a sub-discipline within Social Anthropology in the 1940s. Three quarters of a century later, it has become a very fruitful theoretical and research field. This work has two principal goals. Firstly, a precise characterization of the discipline is developed, highlighting its main features, most relevant issues and most outstanding contributions. Secondly, chronologically, the most important theoretical currents are described from their origins to the present: evolutionists, structural-functionalists, processors, contemporary critical trends, etc. The text ends with a series of challenges that the discipline has ahead. currents.

KEY WORDS: Political Anthropology - Theoretical legacy · Main issues · Diversity of 
«Antropologia berez politikoa da, Politikarekin topatzen delako etengabe» (Ernest Gellner).

\section{Politika eta Antropologia Politikoa definitu nahian}

Antropologia Politikoaren definizioari ekin baino lehen «Politika» kontzeptuaren inguruko hausnarketa egitea ezinbestekotzat jotzen dugu. Zergatik? Lehenengo antropologoek eta gerokoek ere kontzeptu horren definizio komuna egiteko arazo nabarmenak izan zituztelako. Izan ere, «Politika» kontzeptua definitzea izugarri zaila da, askotariko ikuspegiak eta oso ezberdinak daude ikertzaileen artean eta behin baino gehiagotan ez da erraza izan zehaztea zein den ikergai politikoa eta zein ez.

Henri J.M. Claessen-ek, Antropologia Politikoaren egile klasiko batek, «Politika» kontzeptuaren inguruko definizio anitz zeudela ohartarazi zuen aspaldian. Haren ustez, behin baino gehiagotan «definizioak kontrajarriak dira». Radcliffe-Brown antropologo britainiarraren ustez, adibidez, «Politika» zera litzateke: «Ordena sozialaren ezartzea edota mantentzea lurralde-eremu baten barruan, aginte hertsatzaile eta antolatu baten bitartez, eta indarkeria fisikoaren erabilera kontrolpean izanda». Definizio horretan, ordena, hertsadura eta lurraldea oinarrizko aldagaiak dira, baina ikuspegi hori kritikatua izan da hainbat arrazoirengatik: "Politika» soilik erabil daiteke ordena mantentzeko? Zergatik ez kontrakoa egiteko, hau da, ordena apurtzeko? Beti al dago lurralde zehatza? Indarkeriaren erabilera gehienetan fisikoa da? Bestalde, Claessenen arabera, definizio horren arazo nagusietakoa haren ikuspegi estatista litzateke; izan ere, "Estatu»aren ideia etengabe presente dago eta kanpoan utziko lituzke estaturik gabeko gizarteak (Claessen, 1979: 4).

Pierre Clastres-ek ere horrelako definizioen aurrean kontra egiten du, izaera mendebaldarra eta estatista adierazten baitute: «hertsadura eta mendekotasuna ez dira botere politikoaren oinarriak beti eta leku guztietan»; "gure ikuspegi kulturala da botere politikoa ulertzen duena harreman hierarkiko eta autoritarioen arabera, ordena eta obedientzian oinarrituta»; horrexegatik "ordena eta obedientziarik ezak irudikatuko luke botere politiko falta», are gehiago, «botererik gabeko gizarteak». Clastresek baieztatzen du: «Erabakitzen denean (Mendebaldetik) kultura batzuek ez dutela botere politikorik gure errealitatearekin zerikusirik ez dutelako, gure ikuspegiak galtzen du indar zientifikoa» (Clastres, 1978: 12-16).

Beste antropologo klasikoek «Politika»ren izaera «publikoa» azpimarratu nahi izan zuten. Morton Fried-ek, Estatu Batuetako antropologo ospetsuak, «Politika» edo «antolakuntza politikoa gizarte-antolakuntzaren atal bat» zela eta bereziki «izaera publikoa zuten jarduerak kudeatzeaz» arduratzen zela esan zuen (Kottak, 2011: 205). Swartz-ek, Turner-ek eta Tuden-ek Political Anthropology lan klasikoan, «Politika» kontzeptua definitzearen zailtasuna onartu zuten, baina aldi berean definizio zehatz bat ematera ausartu ziren. Haien ustez, «Politika»k 3 ezaugarri nagusi zituen: lehenik, «prozesu politiko bat publikoa da eta ez pribatua»; bigarrenik, «Politika» egitea «helburuak bilatzea» da, «helburu publikoak»; eta hirugarrenik, «Politikaz» hitz egitea «botereaz» solastatzea da (Swartz, Turner eta Tuden, 1994: 103-105). Gaur egun, aipatutako definizioak nahiko zaharkituta gelditzeaz gain, oso 
polemiko bihurtu dira arrazoi batengatik: korronte teoriko ezberdinek «pribatua ere politikoa dela» aldarrikatzen dute, eta, horren ondorioz, "Politika» mugatzea eremu publikora ez da inondik inora onartzen. Feminismoak, adibidez, 60ko hamarkadaz geroztik «pertsonala politikoa dela» baieztatu zuen, eremu pribatu barruko botereharremanak ikusarazi nahian.

Hori dela-eta, «Politika» gizarte-eremu guztietan islatzen den errealitatea izango litzateke. Held eta Leftwich-ek proposatzen duten definizio holistikoak ikuspegi horrekin bat egingo luke: «Gure ustez politika talde eta instituzio (formalak eta informalak) guztietan egoten da, bai esparru publikoan baita pribatuan ere. Egitura eta harreman guztietan agertzen da, ekoizpen-arloan baita erreprodukzio-eremuan ere (...) kooperazio-, negoziazio- eta gatazka-arloetan topatzen dugu (...) gure bizitzaren esparru guztiak baldintzatzen ditu (...) ez da mugatzen soilik gobernura (...) politikatik kanpo utzi nahi izatea hainbat gai ezer baino politikoagoa da» (Caminal, 2005: 29). Dena den, definizio horrek duen arazoa nagusia honakoa da: «Politika»ren mugak zehaztea ezinezkoa da eta orduan dena da politika, eta aldi berean, «dena ekonomia eta dena kultura da» (Caminal, 2005: 31).

Dena den, «Politika» hainbat erregulaziorekin lotuta dagoela ukaezina da. Conrad Kottak-en arabera «Politika»k ekarri ohi du «erabakiak hartzea», nolabaiteko «kontrol soziala» izatea eta «gatazkak konpontzen saiatzea». Kottaken iritziz «Politikaz» hitz egiten dugunean «botereaz» eta «aginteaz» hitz egin behar dugu halabeharrez. Boterea «besteek zure borondatearekin bat egin dezaten gaitasuna erakustea» izango litzateke eta aginteak «boterearen jardutea oniritzi sozialarekin» adieraziko luke (Kottak, 2011: 205). Ronald Cohen-ek irakurketa antzekoa egiten du: «Gizarte-harremanetako aldagai politikoak boterearekin eta agintearekin lotuta daude»; boterea «besteen portaeran eragiteko gaitasuna» izango litzateke eta aginteak «legitimatutako boterea» adieraziko luke (Cohen, 1979: 34).

Antropologiaren ikuspuntutik, «Politika» ezaugarritzeko beste alderdi bat kontuan hartu behar dugu: haren «irudikapena». Marc Abeles-ek «Politikaren antzezpenaz» hitz egiten du eta Georges Balandier-ek «dramatizazio politikoa» aipatzen du. Abelesek gogora ekartzen du «Politika» «agertoki»aren gainean garatzen dela, antzinako politika zein garaikidea (Abeles, 1997: 6). Balandierren ustez, «aktore politiko guztiak antzerkigintzan aritzen dira» eta «botere politiko guztiak antzerkiaz baliatzen dira obedientzia lortzeko, espektakularizazio-maila ezberdinak erabiliz gizartearen arabera» (Balandier, 1994: 15-23).

Orain Antropologia Politikoa ezaugarritzeari ekingo diogu. Hasteko, ezin dugu ahaztu Gizarte Antropologiaren azpidiziplina honek definizio ezberdinak izan dituela une historikoaren arabera. Jaio zenean politika ikertzen zuten gainerako gizartezientzietatik (Zientzia Politikoa, Soziologia Politikoa, Filosofia Politikoa eta abar) oso erraz ezberdintzen zen, baina praktika transdiziplinarioek aurrera egin ahala Antropologia Politikoak birdefinitu behar izan du bere burua.

Hastapenetan, XX. mendeko 40ko hamarkadan eta lehenengo urteetan zehar, Antropologia Politikoak «Politika» ikertzen zuen Mendebaldekoak ez ziren gizarteetan, hau da, industriaurreko gizarteetan, gizarte «arkaiko»etan, gizarte 
«sinple»etan. Horrela lortu zuen ezberdintzea Zientzia Politikoa eta Soziologia Politikoa, zeinak arduratzen ziren Mendebaldeko gizarteez, hots, Europa eta Amerikako Estatu Batuetako «Politikaz». Marc Abeles antropologo frantziarraren arabera, horren ondorioa izan zen «modernitateari buruzko ikerketen monopolioa uztea politologo eta soziologoen esku» (Abeles, 1997: 2).

Duela 4 hamarkada George Balandierrek eman zuen definizioa lehenengo garaiaren ikurra da: «Antropologia Politikoa Gizarte Antropologiaren ikerketa-eremu zehatza da» eta zeregin nagusia du «deskribatzea eta analizatzea gizarte primitibo edo arkaikoen sistema politikoak (egiturak, prozesuak eta irudikapenak)»; «exotismo politikoa» eta «beste forma politikoak» ezagutzera eman behar ditu (Balandier, 1976: 7-8).

70eko hamarkadaz geroztik, Abelesek dioenez, ikerketa antropologikoak «Mendebaldeko gizarte aurreratu»en gaiak jorratzen hasi ziren. Horren ondorioz, Antropologia Politikoak bere burua berregokitu behar izan zuen (Abeles, 1997: 2). Definizio berriek, gaurkotuak, ikertutako gizarte eta sistema politikoen aniztasuna azpimarratzen dute (Kottak, 2011; Castro eta Rodríguez, 2009; Smith, 1979; Cohen, R., 1979: 28; Krader eta Rossi, 1982: 8). Kottakek, adibidez, baieztatzen du: Antropologia Politikoa botereari eta aginteari buruz aritzen da «gizarte eta komunitate ezberdinetan», estatua dutenetan eta estaturik gabekoetan (Kottak, 2011: 204-205). Pablo Castro-k eta Luis Rodríguez-ek (2009: 108) honako definizio hau ematen dute: Antropologia Politikoa askotariko gobernu motak ikertzeaz arduratzen da eta aldi berean «Politikaren loturak» beste esparru sozialekin kontuan hartzen ditu («boterearen gurutzaketak fenomeno kulturalekin») (Castro eta Rodríguez, 2009: 108).

Emilio Duharte-k (2006: 6) definizio gaurkotuago bat eman du: «Antropologia Politikoa Gizarte eta Kultur Antropologiaren atal bat da eta haren helburua gizarte ezberdinen sistema politikoak eta botere-egiturak ikertzea da. Mota guztietako gizarteak ikertzen ditu, ahaidetasunean oinarritutako sinpleenak ("primitiboak", "tradizionalak" edo "exotikoak"), garapen-bidean daudenak eta gaur egungo estatu-gizarte konplexuenak. Analisia egiteko metodologia propioa erabiltzen du: "bestea"ren behaketa sistematikoa» (Duharte, 2006: 6).

Enrique Luque-k nabarmentzen du Antropologia Politikoaren eta beste diziplina politiko (Filosofia Politikoa eta Zientzia Politikoa) batzuen arteko harreman historikoa «zaila eta behin baino gehiagotan gatazkatsua izan dela». Haren ustez hori normala da, zeren Antropologia Politikoaren «funtzioa ez baita filosofo edo politologoaren diskurtsoa errepikatzea, haren proposamen batzuk zalantzan jartzea baizik» (Luque, 1984: 71-73). Elizabeth Colson-en iritziz «Zientzia Politikoak ez zuen oinarri teoriko egokirik analizatzeko estaturik gabeko gizarteek erabiltzen zituzten tresnak bortizkeria kontrolatzeko eta kohesioa lortzeko». Horrexegatik Antropologia Politikoaren agerpena ezinbestekoa izan zen (Colson, 1979: 23).

Hala ere, Cañedo-ren ustetan Antropologia Politikoak «egitura politikoen heterogeneotasuna ulertzeko» ahalegin handia egin arren, beti izan du arazo estrukturala, alegia, bere tresna-kutxaren izaera mendebaldarra analisia egiteko: «Egitura politikoen heterogeneotasuna ulertzeko gure abiapuntua, beti, izan da gure ikuspegi 
mendebaldarra politika ulertzeko. Horren arabera beti estatua, legea, instituzioak, lidergoa eta boterea maximizatzeko portaeren bila ibiltzen gara» (Cañedo, 2013: 1).

\section{Gaiak, metodologia eta ekarpenak}

Antropologia Politikoak askotariko gaiak jorratu ditu eta gai horiek ezberdinak izan dira une historikoaren arabera. Hastapenetan, lehen esan dugun bezala, ikergaiak Mendebaldekoak ez ziren gizarteekin lotuta zeuden eta, ondorioz, sistema politiko mota horien ezaugarriekin. Beraz, lantzen ziren gaiak honakoak ziren: industriaurreko sistema politikoen sailkapena eta ezaugarritzea, historiako lehenengo estatuen sorrera eta eboluzioa, ondorengotza politikoa eta lidergo motak, politikaren eta erlijioaren arteko lotura, antolakuntza politiko aurremodernoaren egitura eta funtzioak (Lewellen, 1994), ahaidetasunaren eta botere politikoaren arteko harremana gizarte tradizionaletan (Abeles, 1997).

Lehenengo garaian sistema politikoen sailkapena garrantzi handiko gaia izan zen. Hainbat antropologoren arabera (Kottak, 2011: 206-223; Claessen, 1979), Elman Service-k proposatutako tipologia ontzat hartu zen sistema politikoak ezberdintzeko historian zehar. Servicek jendartearen historia 4 sistema politikotan banatu zuen: lehenik, «bandak», bigarrenik, «tribuak», hirugarrenik, «buruzagitzak» eta laugarrenik, «estatu primitiboa» (industriaurrekoa). Ikuspegi ebolutibo batetik abiatuta gizarte guztiak pasatzen ziren sistema politiko «sinpleenetik» (bandak) «konplexuenera» (estatua). Lehenengo 2 sistema politikoak (bandak eta tribuak) «sistema politiko ez-zentralizatu»tzat hartzen ziren eta beste biak (buruzagitzak eta estatua) «sistema politiko zentralizatu»tzat (Kottak, 2011: 206). Ikerketa eta egile garrantzitsuenetako batzuk honakoak izan ziren: Elman Service (Primitive social organization: an evolutionary perspective, 1962), Morton Fried (The evolution of political society: an essay in political anthropology, 1967), eta Ronald Cohen \& John Middleton (Comparative political systems: studies in the politics of pre-industrial societies, 1967).

Beste ikergai klasiko bat «estatuaren sorrera» izan zen eta bereziki instituzio horren sorrera ahalbidetu zuten arrazoiak. Hainbat teoria sortu ziren lehenengo estatu historikoen sorrera ulertarazteko, besteak beste: «Barne-gatazkaren teoria», «Kanpo-gatazkaren teoria», «Teoria hidraulikoa», «Teoria demografikoa», «Lidergoaren teoria» eta «Sistema-teoria». Zenbait ikerlan esanguratsu honakoak izan ziren: The origin of the State (Robert Lowie), The Early State (Henry Claessen \& Peter Skalnik), eta Origins of the State: The anthropology of political evolution (Ronald Cohen \& Elman Service).

Abelesek gogoratzen du politika txertatua dagoela edo kudeatzen dela beste instituzioen bidez (ahaidetasuna, erlijioa eta abar) gizarte tradizionaletan. Aldiz, mundu modernoan politika autonomoagoa da instituzio politiko zehatzak baitaude, bestak beste, gobernua, parlamentua, estatua... (Abeles, 1997: 1). Horrexegatik, Duharteren arabera, lehenengo garaiaren gai nagusietakoa izan zen politikaren erregulazioa, politikoak ez ziren instituzioen bitartez. Garai hartako beste gai garrantzitsu bat mito, sinbolo eta errituen eragina politikaren nondik norakoan ikertzea izan zen (Duharte, 2005: 2). 
Balandierrek beste hainbat gai klasiko azpimarratzen du: «Antolakunde politiko tradizional eta moderno"en arteko harremana, eta trantsizioa gobernu tribal eta estatu tradizionaletatik estatu modernoetara. Egile horrek gogora ekartzen du politologo batzuek gizarte tradizionalak ikertzeari ekin ziotela (Balandier, 1976: 11). Balandierrek Raymond Aron politologo ospetsua aipatzen du baieztatu zuenean honakoa: "Gizarte azpigaratuak oso erakargarri bihurtzen ari dira hainbat politologorentzat, batez ere probintzialismo mendebaldar eta industrialetik aldentzeko» (Balandier, 1976: 8).

70eko hamarkadatik aurrera, Abelesen aburuz «Mendebaldeko gizarte aurreratuek interesa piztu zuten» antropologo politikoengan. Horren ondorioz, antropologoen eta politologo/soziologoen arteko banaketa tradizionala zalantzan jartzen hasi zen. Hala ere, Abelesek berak dioenez, banaketa berri bat agertu zen: Antropologia Politikoa politika lokal eta komunitate txikiez arduratu zen eta beste diziplinek estatuari eta politika nazionalari arreta jarri zieten: «Antropologoek beren burua mugatu zuten eremu lokalari buruzko ikerketak eginez. Horrela, banaketa berri bat egin zen: periferia etnologoentzat eta zentroa (politika nazionala eta estatua) beste ikertzaileentzat» (Abeles, 1997: 4).

Dena den, garai horretatik aurrera ikerketa antropologikoak egiten hasi ziren beste gizarte-zientzietan jorratzen ziren hainbat gairen inguruan, besteak beste «nazionalismoa». Ernest Gellner (Nations and Nationalism, 1983) eta Benedict Anderson-en (Imagined Communities, 1983) lanek oihartzun handia lortu zuten «nazioa eta nazionalismoa» ikerketen eremuan.

Abelesek aipatzen ditu garai berri horretako gai esanguratsuenak. Alde batetik, gai «tradizional»en berreskurapena baina egokituta Mendebaldeko gizarte modernoetara, esate baterako, erritu eta sinbolo politikoen garrantzia egungo errealitatean. «Politikaren eszenifikazioa» Mendebaldean eta «zeremonia politiko moderno"en azterketari ekin zioten, hau da, hauteskundeak, manifestazioak, mitinak eta telepolitika ikergai bihurtu ziren. Beste alde batetik, gizarte-zientzietako gai berrienek ere ikerketa antropologikoaren arreta piztu zuten, besteak beste, "globalizazio/mundializazio» prozesua eta iraultza teknologikoaren eragin eta ondorio politikoak (1997: 6).

90eko hamarkadaz geroztik gizarte-zientzia guztietan globalizazioari buruzko ikerketek eta teorizazioek sekulako garrantzia hartu zuten eta hori islatu zen Antropologia Politiko eta Ekonomikoan ere. Zenbait antropologoren lanak nabarmendu ziren, besteak beste, Néstor García Canclini-ren La globalización imaginada (1999), Renato Ortiz-en Mundialización y cultura (1997), Ulf Hannerzen Transnational Connections: Culture, People, Places (1998), Arjun Appadurai-ren Modernity at large: Cultural dimensions of Globalization (2001), eta Marc Abelesen Anthropologie de la globalisation (2008).

Aurora Marquina-ren arabera, aipatutako gaiei beste batzuk gehitu behar zaizkie: «biolentzia»ri buruzkoak eta "gizarte-mugimendu berri»en ingurukoak (etnikoak, ekologistak, feministak, erlijiosoak...). XXI. mende honen hasieran gizarte- 
mugimenduei buruzko ikerketa antropologikoak hazi dira nabarmen eta Espainiako Estatuan, adibidez, lan etnografiko ugari egiten ari dira (Marquina, 2004).

Antropologia Politikoak gai «politologikoagoak» edo «soziologikoagoak» ikertzen hasteko egindako apustuak, eta, alderantziz, gizarte-zientzia horien interesak gai «antropologikoago »etan, diziplinen arteko mugak malgutu eta ikerketa transdiziplinarioagoak ahalbidetu dituzte. Horrek behartu du Antropologia Politikoa indartzera bere ezaugarri nagusia, metodologia, alegia. Gaur egun antropologo politiko askok hainbat ikergai partekatu dezakete beste ikertzaile batzuekin (politologoekin, soziologo politikoekin), baina desberdintasuna mantenduko dute metodologiari dagokionez, landa-lana garatuz etnografiaren bitartez. Antropologia Politikoak bere izaerari eutsiko dio ikerketa-teknika antropologiko zehatzak erabiliz, besteak beste, behaketa sistematikoa eta orokorrean landa-lana denbora luzez eginez.

Antropologia Politikoak hainbat ekarpen egin du bere ibilbide historikoan gizartezientziei begira. Lehenik, «estaturik gabeko gizarte primitibo»en ikerketa ugari egiteak erakutsi du «Politika» topatu dezakegula leku eta eremu ezberdinetan, instituzio estatal modernoetatik haratago. Hau da, «Politika» ere «politikarik gabeko gizarteetan» presente dago, baina beste modu batez kudeatzen da (Duharte, 2005: 7-8).

Bigarrenik, «mito eta sinboloen garrantzia politika ulertzeko» eta haien eraginkortasuna «boterea justifikatzeko eta sakralizatzeko» (Duharte, 2005: 7). Abner Cohenen (Political Anthropology: The analysis of the simbolism of Power Relations) lana aitzindaria da esparru honetan. 60ko hamarkadaren bukaeran Cohenek honakoa esan zuen: «Nire iritziz, Antropologia Politikoaren ekarpen garrantzitsuena eta baliotsuena ez da izan sistema politikoen sailkapena, baizik eta sinbolismoaren garrantzia azpimarratzea botere-harremanak ulertu ahal izateko» (Cohen, 1979: 72)

Hirugarrenik, «Politika» ulertzea oso lotuta dago beste instituzio batzuekin: «Ezin da banatu ahaidetasunetik, adin-taldeetatk, erlijiotik eta talde sekretuetatik» (Duharte, 2005: 7). Gizarte batzuetan agintea eta boterea garatzen da instituzio horien bitartez, gobernu formalik ez baitago. Gizarte «primitibo»etan adibidez, politika kudeatzen zen beste instituzio batzuen bidez (familia, elite erlijiosoa eta abar). Aldi berean, gizarte modernoen politika ere ezin da ulertu kontuan hartu gabe instituzio modernoen eragina (enpresarien taldeak, lobbyak, eliza berriak...).

Azken ekarpena, Duharteren arabera, erakunde eta harreman informalei dagokie, erabaki politikoak ulertu ahal izateko behin baino gehiagotan: «Zientzia politikoak antropologo politikoen eragina izan du; izan ere, horiek erakutsi dute zer-nolako garrantzia duten instituzio informalek sistema politiko guztietan, baita modernoetan ere». Hainbat eremu informaletan (jatetxeak, hotelak...) hartzen dira garrantzi handiko erabakiak eta gero modu ofizialean ontzat hartzen dira eremu formaletan (parlamentuetan, gobernuetan...). Hau da errealitate bat ukaezina, «beste» gizarteetan baita «gure» gizarteetan ere (Duharte, 2005: 8). 


\section{Eboluzio historikoa}

\subsection{Aitzindariak: eboluzionistak}

Nor izan ziren Antropologia Politikoaren aitzindariak zehaztea ez da erraza, ikertzaile bakoitzak irizpide ezberdinak erabiltzen dituelako. George Balandierren ustez, Antropologia Politikoa "oso egitasmo zaharra" da "Aristotelesen Politikan topatzen dugulako». Horren arabera, Antropologia Politikoaren hastapenak eta beste diziplina politikoenak garai berekoak izango lirateke eta Grezia klasikoan eta Mendebaldeko pentsamenduan kokatuko lirateke (Balandier, 1976: 7).

Hala ere, Balandierrek berak zehazten du benetako aitzindariak «XVIII. mendeko pentsalari politikoak» izango liratekeela. «Montesquieu izango litzateke aitzindari handiena». Balandierren aburuz, Montesquieu «Antropologia Politikoaren sortzaileetako bat» izango litzateke «Europakoak ez ziren tradizio politikoak» mahai gainean jarri zituelako, «ekialdeko despotismoaren kontzeptua asmatu zuenean». Montesquieuk gizarte ezberdinetako hainbat gobernu mota identifikatu eta sailkatu zuen Antropologiak duen metodo konparatiboa erabiliz. Bere obra nagusian ( $D e$ l'esprit des lois), "gizarte ezberdinen aniztasunaren inbentarioa egiten saiatu zen». Balandierrek Rousseau ere aldarrikatzen du «herri basatien bizimodua behatu zuelako zientifikoki» eta «gizarte ezberdinen ikerketa konparatiboa goraipatu zuelako", gizarte bakoitza bere burua hobeto ulertzeko baliagarria zelakoan (Balandier, 1976: 9-13).

Dena den, XIX. mendera arte ez dira agertuko benetako aitzindari antropologikoak. Ted Lewellen-ek zehazten duenez, «gizarte primitiboen ezaugarri politikoen ikerketa antropologikoa diziplinaren hastapenetan topatzen dugu», hau da, XIX. mendean. Hala ere, aipatu mendearen bigarren zatian eta XX. mendearen lehenengo hamarkadetan Antropologia barruko banaketa ez zen egiten azpidiziplinen arabera, korronte teorikoen arabera baizik: garai hartan antropologoak ziren «eboluzionistak, historizistak edo estruktural-funtzionalistak» eta ez «antropologo politikoak, etnolinguistak edo ekologo kulturalak» (Lewellen, 1994: 17).

Darwinen teoria eboluzionistak Gizarte Antropologiaren norabidea markatu zuen XIX. mendeko bigarren zatian. Ikuspegi eboluzionistak «zurrunak eta sinplistak» ziren eta garaiko ikerketak «basatiak inoiz ikusiak ez zituzten aretoko antropologoek» gauzatu zituzten. Hala eta guztiz ere, «eboluzionistek Antropologia moderno eta zientifikoaren oinarriak jarri zituzten» (Lewellen, 1994: 18).

Hainbat adituren ustez (Balandier, 1976: 15; Lewellen, 1994: 18; Fábregas, 2014: 13; Colson, 1979: 20), Henry Maine izan zen ikerketa antropologiko-politikoa garatu zuen lehenengo egilea, Antropologia Politikoa diziplina modu ofizialean jaio baino lehen. Horrexegatik aitzindaritzat jotzen da. Lewellenek gogoratzen du egile klasiko guztientzat (Greziatik llustraziora) «gobernu eta politika zibilizazioaren ondorioak zirela». Hori dela-eta, gizarte primitiboetan «ez zegoen politikarik». Maine ikuspegi horren aurka azaldu zen eta bere liburu famatu batean (Ancient Law, 
1861), antolakuntza politikoa gizarte primitiboetan ahaidetasunean txertatzen zela baieztatu zuen. Haren ustez, «ahaidetasuna oinarrizko egitura soziopolitikotzat jo daiteke» (Lewellen, 1994: 18). Fábregas-en ustetan baieztapen hori «sinpleegia» iruditu ahal zaigu gaur egun, baina garai hartan ekarpen handia izan zen (Fábregas, 2014: 13). Michael Smith-en iritziz Antropologia Politiko garaikidea «XIX. mendeko antropologo eboluzionistekin zorretan dago» (Smith, 1979: 9).

Henry Mainek, Ancient Law liburuko 5. kapituluan, «gizarte primitibo eta antzinako zuzenbide»ari buruz hausnartu zuen eta gizarte primitiboaren oinarria familia patriarkala zela ondorioztatu zuen: «giza espeziearen oinarri primitiboa estatu patriarkala izan zen»; "antzinako gizartearen oinarria familia zen eta gizarte modernoarena norbanakoa» (Maine, 1893: 87-90).

Mainek oso argi adierazi zuen gizarte primitiboan familia edo «odol-komunitatea» komunitate politikoaren oinarria zela:

Oinarrizko taldea familia batua da, non adin altuena duen gizonak agintzen duen. Familien elkarketa gens edo etxea da eta tribuen elkarketa Errepublika da. Hori dela-eta, Errepublika norbanako askoren elkarketa da, baina familia primitiboa oinarria izanik. Argi eta garbi dago antzinako gizarte guztiek onartzen zutela enbor beretik zetozela, eta haien batasun politikoa ideia horretan oinarritzen zen. Ideia politikoen historia hasi zen odol-komunitatea komunitate politikoaren oinarria zela onartu zenean (Maine, 1893: 91).

Beste aitzindari garrantzitsu bat Lewis Henry Morgan izan zen. Morganek Mainen ikuspegia bereganatu zuen eta gehiago garatu zuen ikerketa ospetsu batean (Ancient Society, 1877). Morganek ikuspegi eboluzionistatik abiatuta, Historia 3 garaitan banatu zuen: «basatasuna», «barbaro-aroa» eta «zibilizazioa». Haren ustez, eboluzio hori garatu zen munduko gizarte guztietan. Morganen aburuz, "gobernu mota guztiak 2 modutan banatzen dira»: lehenengoa, kronologikoki, «harreman pertsonal hutsetan oinarritzen da eta "societas" deitu daiteke» («Gens» da antolakuntza honen oinarria); bigarrena, «lurraldean eta jabetzan oinarritzen da eta "civitas" (estatua) deitu daiteke» (Morgan, 1971: 77-80).

Gizakiak 2 gobernu mota garatu ditu (...) Lehenengoa eta zaharrena, gens, fratria eta tribuetan oinarritutako gizarte-antolakuntza izan zen. Bigarrena, beranduago, lurraldean eta jabetzan oinarritutako antolakuntza politikoa izan zen. Lehenengo gobernu motan, gobernatzen zen gens eta tribuen harremanen bitartez. Bigarrenean, gizarte politikoa sortu zen eta gobernuak bere eginkizunak gauzatzen zituen lurraldeharremanen bitartez, hau da, herriaren, distrituaren edo Estatuaren bitartez. Gobernu mota bakoitza gizarte zehatz bati lotuta dago: lehenengoa antzinako gizarteari eta bigarrena gizarte modernoari (Morgan, 1971: 126).

Morganen ideia eboluzionistak Friedrich Engels-ek bereganatu zituen bere liburu ospetsuan (The origin of the Family, Private Property and the State, 1884). Lan horretan (marxismoaren klasiko bat) Engels gizakiaren eboluzio historikoa (politikoa eta ekonomikoa) azaltzen saiatu zen, gizarte primitiboetatik kapitalismora. Haren ustez, historian zehar gertatu diren gizarte-klaseen banaketak ekoizpen-bitartekoen 
pribatizazioarekin lotuta daude guztiz. Aldi berean, klase menderatzaileen esku pilatutako botere politikoa aurrekoaren ondorio zuzena da. Klase hori izango da estatua sortuko duena bere pribilegio ekonomikoak babesteko (Engels, 1977)1.

\subsection{Sortzaileak: estruktural-funtzionalismoa}

XX. mendearen hasieran Antropologiaren barruan 2 aldaketa esanguratsu gertatu ziren: alde batetik, teoria eboluzionistaren aurkako jarrerak indarra hartu zuen; beste alde batetik, Estatu Batuetako antropologoen eta Europako (Frantziako Estatua eta Britainia Handia) antropologoen artean apurketa teorikoa gertatu zen. Frantziako Estatuan Emile Durkheim-ek korronte teoriko estrukturalista ${ }^{2}$ bultzatu zuen eta Ingalaterran «funtzioa» eta «egitura» kontzeptuak ikerketa antropologikoaren erdigunean kokatu ziren (Lewellen, 1994: 21-22).

Aitzitik, AEBn Franz Boas-en «historizismoa» ikuspegi teoriko nagusi bihurtu zen. Robert Lowie izan zen ikuspegi eboluzionistari eutsi zion bakanetakoa. The origin of the State (1927) liburuan Lowiek eboluzionismo lineala kritikatu zuen, gizarte guztiak pasatzen ez zirelako «estadio" guztietatik, baina eboluzioaren kontzeptua mantendu zuen. Haren ekarpen esanguratsuena «elkarte» kontzeptuaren erabilera izan zen «konplexutasun politikoa» azaltzen saiatzeko. Lowieren iritziz, «elkarteak ahaidetasunaren mugak eta maila lokalean sortzen diren loturak» gainditzen zituen eta "estatuaren benetako sustraia» erakusten zuen (Fábregas, 2014: 13). Colsonek Lowieren lana aldarrikatu zuen «Amerikako indigenen inguruan egindako ikerketek ekarpen handia egin zutelako Antropologia Politikoan» (Colson, 1979: 22).

XX. mendeko 40ko hamarkadan inflexio-puntu bat egon zen: «Antropologia Holistikoaren ikuspegia» krisian sartu zen antropologo askok "espezializazio handiagoa» eskatzen zutelako. Garai horretan Antropologia Politikoa sortu zen, beste azpidiziplinekin batera Gizarte Antropologiaren barruan (Lewellen, 1994: 17).

Ingalaterran funtzionalismoaren 2 adarren arteko borroka gertatu zen hegemonia lortzeko: Bronislaw Malinowskiren «funtzionalismo psiko-biologikoa» eta RadcliffeBrownen «estruktural-funtzionalismoa». Azken hori gailendu zen bere ikuspegi "estrukturalarekin», zeinaren arabera "gizarte bat oreka-sistema bat den eta atal bakoitzak funtzionatzen duen egitura guztia sostengatzeko». Ez zuen gatazka ukatzen, baina arreta handiagoa jarri zuen ordena mantentzeko baliagarriak ziren «arau, balio eta egitura idealetan». Garai hartako ikerketa gehienak Afrikako kolonia britainiarretan garatu ziren. Lewellen iritziz, «ikerketa haien helburu nagusietakoa zen agintari kolonialei informazio baliagarria helaraztea modu iraunkorrean eta horrek Gizarte Antropologiaren irudia kaltetu zuen» (Lewellen, 1994: 24).

1. Antropologo batzuek Marxen ekarpenak nabarmendu dituzte. Esteban Krotz antropologo mexikarraren ustez, «Marxen ikerlan batzuek ekarpen garrantzitsuak egin zituzten Antropologiari dagokionez» (Krotz, 1996: 9). José González Alcantuden ustez, «Marxen ohar etnologikoek erakusten dute haren interesa Morgan eta Mainen ikerlanetan» (González Alcantud, 1988: 13).

2. Frantziako Estatuan Durkheimez gain, Mauss eta aurrerago Lévi-Strauss aipatu beharko genituzke. Azken horrek Antropologiaren eta Soziologiaren arteko lotura estuak aldarrikatu zituen (Lévi-Strauss, 1969). 
Fábregasek gogora dakartza Malinowskik erabilitako hitz latzak antropologoaren lana zehazteko garai hartan: «Gure jarduerak ez du soilik garrantzi zientifikoa eta kulturala, aldi berean helburu praktiko argia du; izan ere, gizon zuriari lagungarri suertatu ahal zaio hobeto gobernatzeko eta menderatzeko jatorrizko herriak» (Fábregas, 2014: 14).

Aurora Marquinak gogora ekartzen du «egile klasikoek» ikertu zutela «gobernu kolonialen zerbitzura». Garai hartan herrialde «azpigaratuetako» gizakiak primitibotzat jotzen ziren, azpigaratuak, eta horren ondorioz Europa eta AEBko herrialdeen laguntza behar zuten garatu ahal izateko eta ohitura basatiak atzean utzi ahal izateko. «Mendebaldeko etnozentrismoa, kapitalismoa eta kristianismoa (batez ere protestantismoa) ideologia menderatzaileak izan ziren eta ikuspegi horren arabera "besteak" ikertzen ziren” (Marquina, 2004: 13).

1940an Meyer Fortes-ek eta Evans-Pritchard-ek African Political System ikerketa ospetsua argitaratu zuten. Lan horren 2 ardatz nagusiak honakoak izan ziren: Afrika kolonizatua eta estruktural-funtzionalismoa. Aipatu ikerketa Antropologia Politikoaren lehenengo lan ofizialtzat jotzen da (Luque, 1984: 78; Cañedo, 2013:1; Fábregas, 2014: 10; Castro eta Rodríguez, 2009: 109; Colson, 1979: 19; Krotz, 1996: 9). Liburu horretan Fortesek eta Evans-Pritchardek sistema politiko afrikarrak ikertzeko oinarri teorikoak zehaztu zituzten eta aldi berean beste antropologoen etnografiak (Afrikan kokatuak) aurkeztu zituzten.

Liburuaren sarreran Fortesek eta Evans-Pritchardek beren korronte teorikoaren oinarri nagusiak finkatu zituzten. Lehenik, Filosofia Politikoari kritika egin zioten «balio zientifiko gutxikoa» baitzen. Haien ustez, Filosofia Politikoak «nolakoa izan beharko luke»en gizarteak espekulatzen zuen eta ez zuen behaketa zientifikorik egiten ezta konparaketarik ere. Edozein ikerketa zientifikok «induktiboa eta konparatiboa» izan behar zuen. Aldi berean, ikerketak «gizarte-prozesuak funtzio» bihurtu behar zituen eta antzekotasun eta ezberdintasun «estrukturalak» bilatu behar zituen. Fortesek eta Evans-Pritchardek aztertutako gizarte guztiak 2 sistema politikotan banatu zituzten: aginte zentralizatu zutenak eta ez zutenak. Banaketa horren arabera aipatutako 2 sistemak konparatu zituzten hainbat aldagairen inguruan: ahaidetasunaren papera antolakuntza politikoan, demografiaren eta biziraupen moduaren eragina, lurraldetasuna, indarkeriaren kudeaketa, balio mistikoak eta erantzun modu ezberdinak mendekotasun europarraren aurrean (Fortes \& Evans-Pritchard, 2010: 65-88).

1940an Evans-Pritcharden beste 2 liburu argitaratu ziren, Antropologia Politikoaren klasikoak ere: The Nuer eta The Political System of the Anuak. II. Mundu Gerra bukatu ostean Afrikari buruzko ikerketak biderkatu ziren. Hona hemen lan ospetsuenetakoak Balandierren arabera: John Middleton eta David Tait-en Tribes without Rulers (1958) eta Lucy Mair-en Primitive Government (1962) (Balandier, 1976: 17-18).

Estruktural-funtzionalismoaren kritikoek korronte horren zenbait muga nabarmendu zituzten. Hasteko, haren izaera «sinkronikoa» kritikatu zuten; izan ere, gizarteak analizatzen zituzten «haien testuinguru historikotik kanpo», denbora luzez 
«estatikoak» izan balira bezala. Bestalde, «sistemaren oreka» azaltzeko obsesioa salatu zuten, mendekotasun-harremana egonkortzeko funtzio koloniala ezkutuan zegoelako. Lewellenen ustez, ez da kasualitatea «estruktural-funtzionalismoaren beherakada eta II. Mundu Gerra osteko kolonialismo britainiarraren lur-jotzea» une berean gertatzea (Lewellen, 1994: 111-113). Andrés Fábregasek ere kritika luzatzen dio estruktural-funtzionalismoari «boterea lortzeko borroka» eta «mendekotasun»aren fenomenoa bazterrean utzi zituelako (Fábregas, 2014: 10).

\subsection{Trantsizioa eta ikuspegi prozesuala}

50eko hamarkadaren erditik aurrera teoria estruktural-funtzionalista zalantzan jartzen hasi zen hainbat lanetan. Horietako bat Birmaniako «Kachin»ei buruzko ikerketa izan zen, Edmund Leach-ek idatzia (Political Systems of Highland Burma). «Weber eta Radcliffe-Brownen ordez, Pareto eta Levi-Strauss iturri intelektualak izan ziren». Leachek kritikatu zuen sistema politikoak aurkeztu nahi izatea «naturalki» orekatuak egongo balira bezala (Fábregas, 2014: 16). Lan horretan Leachek ezberdindu zituen «egitura politiko abstraktua» eta benetako errealitate politikoa, zeina gatazkatsuagoa zen. Gainera, egileak kokatu zuen «Antropologia Politikoa Afrikatik kanpo», beste kontinente batzuetako gizarteak ikertuz (Lewellen, 1994: 26-27).

Trantsizio teoriko horren beste ikertzaile paradigmatiko bat Max Gluckman izan zen eta bereziki berak idatzitako hainbat liburu, besteak beste, Custom and conflict in Africa (1956) eta Order and rebelión in tribal Africa (1960). Lan horietan Gluckmanek «oreka ez dela estatikoa ezta egonkorra ere» azpimarratu zuen eta errealitate politikoa irudikatu zuen «prozesu dialektiko» baten barruan, non gatazkak ohikoak diren (Castro eta Rodríguez, 2009: 110). «Matxinadak baliagarriak ziren sistema mantentzeko» (Colson, 1979: 24). Matxinadek ordena soziala berreskuratzen zuten, baina egoera berria aurreko ordenarekin alderatuta ezberdina zen (González Alcantud, 1998: 26). Orekaren ideiarekin apurtu ez zuen arren, gatazkaren kontzeptua gehitu zuen eta horrek aurrerapen teoriko garrantzitsua izan zen, ondorengo korronte teorikoen oinarriak jarri zituelako ${ }^{3}$.

Gluckman Manchesterreko Unibertsitateko Gizarte Antropologiaren Saileko sortzailea izan zen eta haren jarraitzaileek Manchesterreko Eskola sortu zuten. Eskola horrek Antropologia Politikoaren norabide teorikoa aldatu zuen, egitura eta funtzioa bigarren mailan kokatuz eta «prozesua eta gatazka» erdigunean jarriz (Lewellen, 1994: 27-28).

Estatu Batuetan Antropologia Politikoak beste norabide bat hartu zuen; izan ere, ikuspegi neo-eboluzionistak berrindartu ziren Leslie White eta Julian Steward-en ikerketen bitartez. Whitek sekuentzia ebolutibo bat proposatu zuen, zeinaren arabera «nekazaritzaren garapenak ekarriko lituzkeen jabetza pribatua, espezializazioa, gizarte-klaseen estratifikazioa eta zentralizazio politikoa». 60ko hamarkadan ikuspegi eboluzionista zuten 2 lan nabarmendu ziren: Elman Service-ren Primitive

3. Gluckmanek kritika zorrotzak jaso zituen «bere ikerketak Zululandian oinarrituta zeudelako, lurralde bat gizon zuriek gobernatua, non barne-gatazkak (...) kolonizatzaileen interesen arabera mediatizatuak zeuden beti» (González Alcantud, 1998: 26). 
Social Organization (1962) eta Morton Fried-en The evolution of Political Society (1967) (Lewellen, 1994: 28-29).

Estruktural-funtzionalismoak 2 hamarkadatan zehar hegemonia izan ostean, zentralitatea galdu zuen korronte teoriko baten agerpenarekin. Hori posible izan zen mundu mailan gertatzen ari ziren aldaketa politiko eta historikoengatik, bereziki Afrikako deskolonizazioari esker eta bertan sortutako estatu independente berrien ondorioz. Beatriz Pérez-ek gogora dakar: «Kolonialismo afrikarraren bukaerak astindu politiko ikaragarria eragin zuen eta ikerketen arreta aldatu zen egitura eta funtzioetatik aldaketa politikoetara. Trantsizio horretan 3 ikertzaile nagusitu ziren: Edmund Leach, Max Gluckman eta Víctor Turner. Lehenengo biek "prozesu" eta "gatazka"ren ikerketari ekin zioten, aurreko korronte teorikoaren gehiegikeriak kritikatuz. Gatazka ez zela salbuespena, ohikoa baizik, azpimarratu zuten». Victor Turner eta F.G. Bailey-k -Gluckmanen ikasleak- Manchesterreko Eskolaren barruan «gatazkaren azterketa erdigunean jartzeaz gain norbanakoaren portaera politikoaren analisiari arreta berezia jarri zioten» (Pérez, 2011: 7).

Lewellenen ustez, "aldaketa teorikoa estrukturalismotik teoria prozesualera» posible izan zen "Afrikako kolonialismoak inposatutako egonkortasun faltsua» bukatu zenean. «Estatu-nazio berrien sorrerak eta gizarte tribalen txertaketak egitura politiko handiagoetan» arazo berriak eragin zituzten. «Politika primitiboa ezin zen ikertu sistema politiko itxi baten barruan». "Sistema» ren kontzeptu zurruna baztertzen hasi zen eta garrantzia hartu zuen berri bat, malguagoa: «lurralde soziopolitikoa». Aldi berean, "gune politiko»aren kontzeptua ere asmatu zen, lurralde soziopolitikoaren barruan eremu txikiagoa zehazteko. "Gune politikoa» baliagarria suertatu zen norbanako zehatzen arteko borrokak (boterea eta lidergoa lortzeko eta mantentzeko) ikertu ahal izateko. Halaber, «egitura» eta «funtzioa» baztertu ahala beste kontzeptu berri batzuk erdigunean kokatu ziren, besteak beste, «prozesu», «gatazka», «borroka», «fakzioa» eta abar (Lewellen, 1994: 30-31).

Teoria prozesualaren hastapenetan ikerketa esanguratsuena izan zen Political Anthropology (1966), Marc Swartzek, Víctor Turnerrek eta Arthur Tudenek koordinatua. 25 urte lehenago estruktural-funtzionalismoarekin gertatu zen bezala (African Political System argitaratu zenean), Turnerrek, Swartzek eta Tudenek lan kolektibo bat koordinatu zuten, zenbait egileren etnografiak aurkeztuta, eta sarrera erabili zuten korronte teoriko prozesualistaren oinarri teorikoak mahai gainean jartzeko. Ikuspegi teoriko berriak «Politika» ulertzen zuen prozesu dinamiko bat izango balitz bezala, non helburu publikoak bilatzen diren eta gatazkak eta borrokak gertatzen diren boterearen inguruan. Gainera, botere mota ezberdinak zehazten zituzten: kontsentsuan oinarritutakoa, hertsadura bitartez garatzen dena eta abar.

Garai hartako beste lan adierazgarri bat honako hau izan zen: Schim \& Continuity in an African Society (1957), Víctor Turnerrek idatzia. Ikerketa horretan egitura politikoari begiratu beharrean Turnerrek hainbat norbanakoren portaera politikoari so egin zion. Lidergoa lortzeko edo mantentzeko norbanako horiek erabiltzen zituzten estrategia manipulatzaileak aztertu zituen. Horrek erabateko aldaketa ekarri zuen; izan ere, pertsona zehatzen portaera politikoetan arreta jartzen zen eta ez taldeen egituran edota praktika politiko kolektiboetan. 
Ikuspegi prozesualaren barruan Abner Cohenen Ekintzaren Teoriak erabateko garrantzia izan zuen. Teoria horren arabera, ikergai berria «norbanakoa zen eta haren estrategia manipulatzaileak boterean mantentzeko edo eskuratzeko». Norbanakoa «homo politicus»tzat jotzen zen, «boterearen maximizazioa» bilatzen baitu. Norbanako gutxiren artean borroka sortzen da boterea eskuratzeko eta horretarako taldeko jendearen babesa bilatzen dute. Dena den, analisi garrantzitsuena aipatutako norbanako horien arteko «aurrez aurreko interakzioa» da (Lewellen, 1994: 129).

Ekintzaren Teoriaren adierazpen zehatz bat Jokoaren Teoria izan zen. Frederik Baileyk garatu zuen teoria hori Stratagems anda Spoils (1969) lan ospetsuan. Baileyren iritziz, «Politika» joko lehiakorra da aldez aurretik adostutako arauekin. 2 arau mota daude: normatiboak («publikoak») eta pragmatikoak («jokoa irabazteko ezinbestekoak direnak»). Egitura politikoak 5 aldagai ditu: sariak, "gatazkan parte hartzen dutenak», lidergo zehatzak, lehia eta epaileak. Talde politikoak 2 motatakoak dira: trinkoak (elkartzen direnak «etekin erreala edo potentziala» dagoelakoan) eta morala (elkartuta «arrazoi etiko» baten inguruan). Baileyk uste zuen 3 aldaketa politiko mota gertatu ahal zirela: errepikakorra, adaptatiboa edo erradikala (Lewellen, 1994: 133-138).

Garai hartako beste ikerketa esanguratsu bat, Beatriz Pérezen arabera, lehen aipatutako Abner Cohenen Political Anthropology: The analysis of the simbolism of Power Relations (1969) lana da. Lan horretan Cohenek «eremu sinbolikoaren eta gune politikoaren arteko harremana" aztertu zuen eta "botere-harremanetan sinboloek izan dezaketen eraginari» erreparatu zion (Pérez, 2011: 8-9).

\subsection{Eztabaida garaikideak}

Beatriz Pérezen ustetan, «Antropologia Politikoaren hurrengo garaia 70eko hamarkadan hasi zen eta egonkortu zen 80 ko eta 90eko hamarkadetan. Lehenengo urteetan Dependentziaren Teoriak eta Sistema-Mundo Teoriak ${ }^{4}$ eragin handia izan zuten giza eta gizarte-zientzia guztietan eta, ondoren, «postmodernismoak» eta «paradigma postestrukturalistek» ere «garrantzi nabarmena» lortu zuten. «Nazio deskolonizatuen askapen-mugimenduen proposamenek, inperialismoaren, kolonialismoaren eta kapitalismoaren aurkako kritikek, eta teoria feministaren planteamenduek galdera berriak mahai gainean jarri zituzten eta interpretazioikuspegi berriak ere zabaldu zituzten» (Pérez, 2011: 2). Garai berri horren ezaugarri adierazgarriak honakoak izan ziren: alde batetik, korronte teorikoen aniztasuna eta, beraz, korronte hegemonikoen garaien bukaera; beste alde batetik, ikuspegi kritiko eta antisistemikoen indarra eta hedapena.

90eko hamarkadan azpidiziplinaren krisia gertatu zen Pérezen arabera: «Boterearen inguruko birdefinizioak eta Gizarte Antropologiaren barruko kritikak krisia eragin zuten eta Antropologia Politikoak dekonstruzio-bideari ekin zion». Azken bolada horretako ikergai berriak honakoak izango lirateke: «Dominazio eta erresistentzia politikoaren forma garaikideak, identitate/alteritatearen politikak, feminismoa eta, zientzia, teknologia eta politikaren arteko loturak» (Pérez, 2011: 2).

4. John Gledhill-en arabera Dependentziaren Teoriak eta Mundu-Sistema Teoriak honako ekarpen hau egin zuten: nazioarteko ikuspegia txertatzea Antropologiaren agendan (2000: 21).

UZTARO 107, 5-22

Bilbo, 2018ko urria-abendua 
Azken bolada horretako ezaugarri esanguratsu bat azpidiziplinaren demokratizazioa da; izan ere, hamaika ikertzaile berri ekarpen esanguratsuak egiten ari dira kontinente eta herrialde ezberdinetatik. Antropologia Politikoaren hastapenetan, lehenengo hamarkadetan, Mendebaldeko herrialdeetako dozena bat gizon izan ziren azpidiziplinaren "ordezkariak», baina orain, mende berriaren hasieran, zerrenda pluralagoa da, generoari, sorterriari eta gizarte-klaseari dagokienez.

XXI. mende honen hasieran, Montserrat Cañedoren ustez, Antropologia Politikoak aurrean duen erronka handienetako bat etnozentrismoaren herentzia zaharra gainditzea da eta, ondorioz, helburu garrantzitsuenetako bat «Antropologiaren deskolonizazioa» da (Cañedo, 2011: 6). Hori dela-eta, gaur egun gero eta ikertzaile gehiago murgiltzen ari dira azterketa postkolonial/dekolonialetan. Eremu teoriko horretan antropologo batzuk erreferente garaikide bihurtu dira, besteak beste, Arturo Escobar, Marisol De la Cadena, Eduardo Restrepo...

Cañedok beste 2 ikerketa-eremuren garrantzia azpimarratzen du, lehen aipatu ditugunak: gizarte-mugimendu berriak eta globalizazioa. Haren ustez, «aktibista politiko askoren borrokek (eskubide zibilen aldeko mugimendua, feminismoa, bakearen aldeko mugimendua, ekologismoa, mugimendu homosexuala eta abar) lortu dute ikerketa akademikoaren erdigunean jartzea gai eta hausnarketa berriak». Eguneroko bizitzaren gatazka inbisibilizatuak (dominazio- eta erresistentzia-praktikak biltzen dituztenak) ikusarazteko ahalegin berezia egin dute zenbait ikertzailek. Bestalde, globalizazioaren inguruko azterketa klasikoez haratago, lokalaren eta globalaren arteko harreman dialektikoak ikertzea ezinbestekotzat jotzen da gure gaur egungo mundua hobeto ulertzeko (Cañedo, 2011: 7-8).

Aurrekoarekin lotuta eta bukatzeko, azken urteotan Antropologia Politikoaren barruan egiten ari diren ikerketa interesgarri batzuk aldarrikatzea gustatuko litzaiguke, bereziki gizarte-mugimendu berrien inguruan, baita haien praktika militante berriei buruzkoak ere: Udaberri Arabiarraren herri-matxinadak, Espainiako Estatuko «15M» mugimendua, Occupy Wall Street, mugimendu indigena eta afroa Latinoamerikako hainbat herrialdetan, egitasmo komunalak zenbait lekutan...

\section{Ondorioak}

XXI. mendearen hasieran, 8 hamarkada pasa ostean lehenengo ikerlana (Sistema Politiko Afrikarrak) argiratu zenetik, Antropologia Politikoak fase ezberdinak pasatu ditu eta gaur egun sortu zenean baino askoz hobeto kokatua dagoela baieztatu dezakegu. Egia da oraindik ez duela lortu politika jorratzen duten beste diziplinek eskuratutako oihartzuna, behintzat zentzu nominalean. Hala ere, ukaezinak dira emandako aurrerapausoak: ikerketa-eremu oparo bihurtu da, askotariko gaiak jorratzen ditu eta, gainera, sekulako ahalegina egin du prozesu politiko garaikide esanguratsuenak aztertzeko. Aldi berean, hainbat antropologo politikok lortu du aitorpen-maila altua Antropologiaren esparrutik haratago, gizarte-zientzia guztietan.

Hemendik aurrera, Antropologia Politikoaren erronka handienetako bat honakoa izango da: bere nortasuna defenditzea bere izaera propioa aldarrikatuz, baina jarrera nartzisista edota autozentratuak ekidinez, «Politika» lantzen duten beste 
diziplinetatik ez urruntzeko. Gaur egun mota guztietako artikulazioak behar ditugu: akademikoak, politikoak baita ideologikoak ere. Gizarte Zientzietako pentsalari kritikoek erantzukizun handia dute lan-esparru komunak bultzatzeko, gure testuinguru politikoa oso gatazkatsua baita eta ziurgabetasun eta arrisku handiz beterik baitago. Egungo antropologo politikoek aipatutako artikulazio horien aldeko apustu irmoa egin beharko lukete, beldurrik gabe, lasaitasun handiz, beren ekarpenak erabat beharrezkoa (ezinbestekoa esango genuke) izaten jarraituko duela jakinda. Hortxe daude, besteak beste, haien tresna metodologikoen kalitatea eta haien gaitasuna kontuan hartzeko epistemologia kritikoak/postkolonialak.

Aipatutako azken hausnarketa honek ikuspegi «kosmopolitikoa» aldarrikatzera garamatza, Montserrat Cañedok proposatzen duen bezala. Izan ere Antropologia Politikoak aurretik duen eginkizun handienetako bat «kosmopolitismo» kontzeptu zaharkitua, inozoa eta mendebaldarretik gatazka onartzen duen «kosmopolitika» kontzeptura jauzi egitea (zeharkatzea) da. Cañedok dioen bezala: «Kosmopolitismoak gatazkarik gabeko unibertsalismo mota batekin bat egiten du normalean; kosmopolitika, aldiz, bizitzeko modu eta ezagutza-praktika ezberdinetatik abiatzen da. Beste modu batez esanda, ontologia pluraletatik abiatzen da eta onartu egiten du ezberdintasun guztiak ezin direla modu baketsuan kudeatu» (Cañedo, 2013: 2).

Azkenik, konpromisoa hartzeko proposamena egiten dugu, zorroztasun akademiko eta intelektualetik abiatuta, gure ahalegin antropologikoen zati handi bat 2 urgentziazko eginkizun bultzatzeko: alde batetik, gizarte ezberdinetan garatzen diren dominazio politikoko dinamikak (mikroak eta makroak) ikusarazteko; beste alde batetik, eta batez ere, agente aktiboak izatea praktika politiko alternatibo eta emantzipatzaileak ezagutarazteko, bertan bestelako mundu politikoak eraikitzen ari baitira.

\section{Bibliografia}

Abeles, M. (1997): «La antropología política: nuevos objetivos, nuevos objetos», Revista Internacional de Ciencias Sociales, 153, 1-15.

(2012): Antropología de la globalización, Ediciones Del Sol, Buenos Aires.

Anderson, B. (1993): Comunidades imaginadas. Reflexiones sobre el origen y la difusión del nacionalismo, FCE, Mexiko.

Appadurai, A. (2001): La modernidad desbordada. Dimensiones culturales de la globalización, Ediciones Trilce, Montevideo.

Balandier, G. (1976): Antropología Política, Ediciones Península, Bartzelona. (1994): El poder en escenas. De la representación del poder al poder de la representación, Paidós, Bartzelona.

Caminal, M. (2005): «La política como ciencia», in M. Caminal, Manual de Ciencia Política, Tecnos, Madril, 19-36.

Cañedo, M. (2011): Antropología Política. Temas contemporáneos, Bellaterra, Bartzelona. , (2013): Cosmopolíticas. Perspectivas antropológicas, Trotta, Madril.

Castro, Pablo eta Rodríguez, Luis (2009): «Antropología de los procesos políticos y del poder», Alteridades, 38, Mexiko, 107-127. 
Claessen, H. (1979): Antropología Política. Estudio de las comunidades políticas (una investigación panorámica), UNAM, Mexiko.

Claessen, H. eta Skalnik, P. (1978): The early state, Berlin.

Clastres, P. (1978): La sociedad contra el Estado, Monte Ávila, Caracas.

Cohen, A. (1979): «Antropología Política: el análisis del simbolismo en las relaciones de poder», in J.R. Llobera, Antropología Política, Anagrama, Bartzelona, 55-82.

Cohen, R. (1979): «El sistema político», in J.R. Llobera, Antropología Política, Editorial Anagrama, Bartzelona, 27-53.

Cohen, R. eta Service, E. (1978): Origins of the State: The Anthropology of Political Evolution, Institute for the Study of Human Issues, Philadelphia.

Colson, E. (1979): «Antropología política», in J.R. Llobera, Antropología Política, Editorial Anagrama, Bartzelona, 19-25.

Duharte, E. (2006): «Antropología Política: ¿una arqueología de la política?», in E. Duharte, (konp.), La Política: miradas cruzadas, Editorial de Ciencias Sociales, Habana, 1-16.

Engels, F. (1977): El origen de la familia, de la propiedad privada y del Estado, Editorial Fundamentos, Madril.

Evans-Pritchard, E. (1977): Los nuer, Editorial Anagrama, Bartzelona.

Fábregas, A. (2014): «El estudio de la vida política en antropología: una evaluación», Colección Apuntes del Sur, 1, Mexiko, 1-55.

Fortes, M. eta Evans-Pritchard, E. (2010): Sistemas políticos africanos, CIESAS, UAM, Mexiko.

Fried, M. (1967): The evolution of political society: an essay in political anthropology, Random House, New York.

García Canclini, N. (2001): La globalización imaginada, Paidos, Buenos Aires.

Gellner, E. (2001), Naciones y nacionalismo, Alianza Editorial, Madril.

, (1995). Antropología y política. Revoluciones en el bosque sagrado, Gedisa, Bartzelona.

Gledhill, J. (2000): El poder y sus disfraces, Bellaterra, Bartzelona.

Gluckman, M. (2009): Costumbre y conflicto en África, Fondo Editorial UCH, Lima.

, (1963). Order and rebelion in tribal Africa, Psychology Press, UK.

González Alcantud, J. (1998): Antropología y política. Sobre la formación cultural del poder, Anthropos, Bartzelona.

Hannerz, U. (1998): Conexiones transnacionales. Cultura, gente, lugares, Ediciones Cátedra, Madril.

Kottak, C. (2011): Antropología cultural, Mc Graw Hill, Mexiko.

Krader, L. eta Rossi, I. (1982): Antropología política, Anagrama, Bartzelona.

Krotz, E. (1996): «Poder, símbolos y movilizaciones: sobre algunos problemas y perspectivas de la antropología política», Nueva Antropología, IX, 31, Mexiko, 7-21.

Leach, E. (1970): Sistemas políticos de la Alta Birmania. Estudio sobre la estructura social Kachin, Editorial Anagrama, Bartzelona.

Lévi-Strauss, C. (1969): «La sociologie française», in G. Gurvitch,(1969), La Sociologie au $X X e$ siècle, PUF, Paris.

Lewellen, T. (1994): Introducción a la antropología política, Bellaterra, Bartzelona.

Lisón Tolosana, C. (1977): Antropología Social en España, Akal, Madril.

Lowie, R. (1962): The origin of the State, Russell \& Russell, New York.

Luque, E. (1984): «Sobre antropología política (diálogo polémico con un viejo discurso)», Revista Española de Investigaciones Sociológicas, 25, 71-94.

Maine, H. (1893): El derecho antiguo (Ancient Law), Escuela Tipográfica del Hospicio, Madril. 
Marquina, A. (2004): El Ayer y el Hoy: Lecturas de Antropología Política. Vol. 1. Hacia el futuro, UNED, Madril.

Morgan, H. (1987): La sociedad primitiva, Endymion, Madril.

Ortiz, R. (1997): Mundialización y cultura, Alianza Editorial, Buenos Aires.

Pérez, B. (2011): Antropología Política. Textos teóricos y etnográficos, Bellaterra, Bartzelona.

Service, E. (1962): Primitive social organitation: an evolutionary perspective, Random House, New York.

Smith, M. (1979): «El estudio antropológico de la política», in J.R. Llobera, Antropología Política, Editorial Anagrama, Bartzelona, 7-15

Swartz, M.; Turner, V. eta Tuden, Ar. (1994): «Antropología Política: una introducción», Revista Alteridades, 4, 8, 101-126.

Turner, V. (1972): Schim \& Continuity in an African Society, Manchester University Press, Manchester.d 

